\title{
Trends in strandings and by-catch of marine mammals in northwest Spain during the 1990s
}

\author{
A. López* ${ }^{\dagger}$, M.B. Santos ${ }^{\ddagger}$, G.J. Pierce ${ }^{\ddagger}$ A.F. González*, X. Valeiras ${ }^{\dagger}$ and A. Guerra* \\ *ECOBIOMAR, Instituto de Investigaciones Marinas (CSIC), Eduardo Cabello 6, 36208 Vigo, Spain. ${ }^{\dagger}$ CEMMA, Apartado 165, \\ 36380 Gondomar, Spain. ${ }^{\ddagger}$ Department of Zoology, University of Aberdeen, Tillydrone Avenue, Aberdeen AB24 2 TZ.

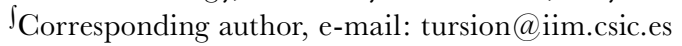

\begin{abstract}
Strandings of marine mammals on the north-western Spanish coast (Galicia) have been systematically recorded since 1990. A total of 1433 marine mammals belonging to 15 species was recorded from 1990 to 1999. The most frequently recorded species stranded were common dolphin $(47 \%)$, bottlenose dolphin $(11 \%)$ and harbour porpoise $(7 \%)$. The number of strandings recorded increased annually over the study period, probably reflecting an increased observer effort. During 1996-1999, an average of 1.65 animals were stranded annually for each $10 \mathrm{~km}$ of coastline, the highest density of strandings recorded on the Atlantic coast of the Iberian Peninsula. More than $80 \%$ of the strandings were located on the western coast of Galicia, mainly in autumn and winter. During the study period, 42 proven incidental catches were recorded, although signs of by-catch were seen in a further 198 animals. The average size of stranded common dolphins and the proportion of males both increased towards the end of the calendar year.
\end{abstract}

\section{INTRODUCTION}

The Galician coastline is characterized by high productivity and high biodiversity (e.g. Solórzano et al., 1988). Galicia is the main fishing region of Spain and one of the most important in the world, with 87 fishing ports used by more than 6500 fishing boats.

At least 19 species of marine mammal (16 of cetaceans and three of pinnipeds) are known to occur in waters off the coast of Galicia, north-west Spain (Penas-Patiño \& Piñeiro-Seage, 1989). Most of the information available on cetacean populations in these waters refers to the larger, previously commercially exploited, species. From 1924 to 1980 there was a fishery in Galicia for sperm whales and rorquals (Aguilar \& Lens, 1981), and studies on rorquals continued until 1985 (Penas-Patiño \& Piñeiro-Seage, 1989). The status of populations of small cetaceans off Galicia remains poorly known. In particular, in view of the intensive fishing activity in the area, it is important to document interactions between cetaceans and fisheries.

Stranding records have been compiled occasionally in Galicia since 1980. However, systematic recording started in 1990, organized by the Coordinadora para o Estudio dos Mamiferos Mariños (CEMMA).

In this study, the strandings data for the decade 1990 to 1999 are used to quantify patterns and trends in mortality, in terms of species composition, sex ratio and size distribution. Basic information on causes of mortality was collated, in particular asking whether there is evidence of substantial fishery by-catch mortality. By examining geographical, seasonal and interannual variation in strandings, we hope to determine where and when most strandings occur and hence provide insight into the underlying causes.

\section{MATERIALS AND METHODS}

Study area

The study area comprises the Galician coast, from the Ría of Ribadeo to the river Miño (Figure 1). The Galician coast has a length of $1195 \mathrm{~km}(50 \%$ with cliffs, 34\% low rocky coast, $16 \%$ beaches), representing $35 \%$ of the Spanish coastline. The Galician coastline is characterized by the presence of a series of large inlets or rías, which are drowned tectonic valleys of moderate depth. The Galician shelf is relatively narrow with a maximum width of $35 \mathrm{~km}$. The shelf ecosystem is influenced by seasonal upwelling, from April to September (Fraga, 1981), which sustains high productivity and high biodiversity. Prevailing winds, hence also wind-driven surface currents, are from the south and southwest in winter, although this is reversed in summer. Galician waters are an important nursery ground for hake Merluccius merluccius, sardine Sardina pilchardus, scad Trachurus trachurus and blue whiting Micromesistius poutassou, among other fish species.

For the purposes of analysis, the study area was divided in six sub-areas, following physical characteristics of the coastline as well as logistic considerations (see Figure 1).

\section{Collection of data}

Marine mammals stranded, by-caught or found floating at sea in Galicia are routinely reported to the local strandings network (CEMMA) by members of the public and fishermen, as well as the local police, Red Cross, local authorities and nature protection services. Whenever possible, specimens are then inspected and identified. In addition, periodic inspections of the coast are undertaken by groups of volunteers, ensuring that a higher proportion 


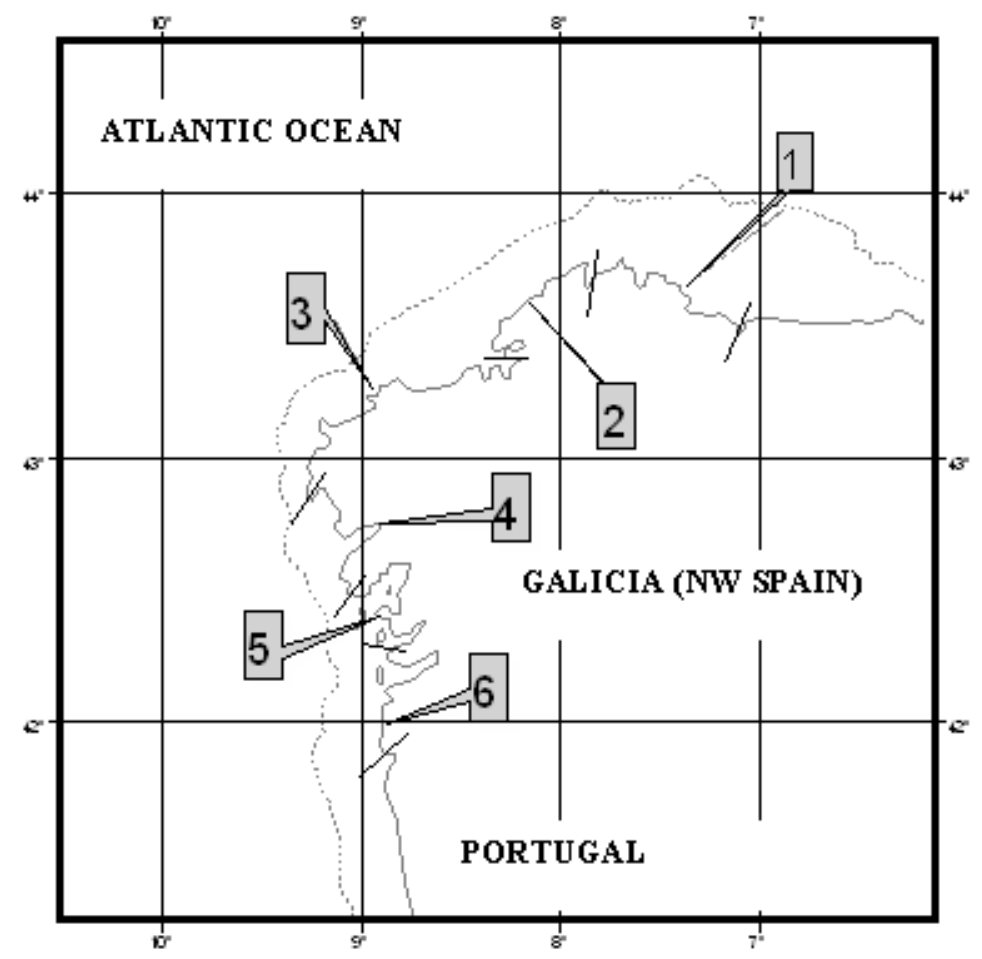

Figure 1. Map of the study area, showing division into six sub-areas.

of reported strandings could be visited. A 24-h phone line and a mobile unit (with vehicle) are in operation for reporting and attending strandings.

For each animal, the state of preservation was recorded as a numerical code, following criteria proposed by the European Cetacean Society (ECS): 1= alive; 2 = freshly dead; $3=$ moderate decomposition; $4=$ advanced decomposition; $5=$ skeletal remains. When possible, biological data (sex, length, weight, other morphometric measurements), biological samples (stomach contents, teeth, gonads, parasites, samples of lungs, kidney, heart, etc.) and photographs were taken.

Small specimens were taken to the laboratory for postmortem examination while larger animals were examined in situ. In all cases, post-mortems were carried out following the ECS protocol, including application of

Table 1. Number of strandings of different marine mammal species recorded annually in Galicia (north-west Spain) 1990-1999. Annual and species totals are given as numbers and as percentages.

\begin{tabular}{|c|c|c|c|c|c|c|c|c|c|c|c|c|}
\hline \multirow[b]{2}{*}{ Species } & \multicolumn{10}{|c|}{ Year } & \multirow[b]{2}{*}{ Total } & \multirow[b]{2}{*}{$\%$} \\
\hline & 90 & 91 & 92 & 93 & 94 & 95 & 96 & 97 & 98 & 99 & & \\
\hline Delphinus delphis & 24 & 43 & 33 & 61 & 46 & 80 & 141 & 76 & 88 & 81 & 673 & 47.0 \\
\hline Tursiops truncatus & 12 & 12 & 15 & 18 & 12 & 13 & 15 & 13 & 24 & 20 & 154 & 10.7 \\
\hline Unidentified cetacean & 12 & 10 & 11 & 10 & 14 & 10 & 9 & 9 & 5 & 12 & 102 & 7.1 \\
\hline Unidentified Delphinidae & 4 & 1 & 1 & 4 & 1 & - & 30 & 32 & 13 & 18 & 104 & 7.3 \\
\hline Phocoena phocoena & 12 & 10 & 3 & 11 & 13 & 6 & 10 & 5 & 14 & 19 & 103 & 7.2 \\
\hline Stenella coeruleoalba & 5 & 6 & 3 & 3 & 12 & 8 & 15 & 9 & 11 & 10 & 82 & 5.7 \\
\hline Globicephala melas & 3 & 9 & 7 & 11 & 4 & 3 & 7 & 11 & 9 & 11 & 75 & 5.2 \\
\hline Grampus griseus & - & 3 & 1 & 4 & 7 & 3 & 10 & 6 & 2 & 6 & 42 & 2.9 \\
\hline Cetacean bones & 1 & 1 & 2 & 5 & 3 & 4 & 3 & 1 & - & - & 20 & 1.4 \\
\hline Globicephala macrorhynchus & - & - & - & - & - & - & - & - & 15 & - & 15 & 1.0 \\
\hline Unidentified rorqual & - & - & - & 1 & 3 & 1 & 4 & - & 1 & 4 & 14 & 1.0 \\
\hline Balaenoptera acutorostrata & 1 & 1 & - & 3 & - & 1 & - & 1 & 1 & 2 & 10 & 0.7 \\
\hline Physeter macrocephalus & 1 & 1 & - & 2 & 4 & - & - & - & - & - & 8 & 0.6 \\
\hline Pinnipeds & - & - & - & - & - & - & - & 4 & 3 & - & 7 & 0.5 \\
\hline Balaenoptera physalus & - & - & - & 2 & 1 & 2 & 1 & - & - & 1 & 7 & 0.5 \\
\hline Kogia breviceps & - & - & - & - & - & 3 & - & 2 & - & 2 & 7 & 0.5 \\
\hline Ziphius cavirostris & 2 & 1 & - & - & - & 1 & - & - & 1 & - & 5 & 0.3 \\
\hline Lagenorhynchus acutus & - & - & - & - & 1 & 1 & - & - & - & 1 & 3 & 0.2 \\
\hline Megaptera novaeangliae & - & - & - & 1 & - & - & - & - & - & - & 1 & 0.1 \\
\hline Orcinus orca & 1 & - & - & - & - & - & - & - & - & - & 1 & 0.1 \\
\hline Total & 78 & 98 & 76 & 136 & 121 & 136 & 245 & 169 & 187 & 187 & 1433 & \\
\hline
\end{tabular}


Table 2. Condition of stranded marine mammals. Total numbers and percentages for each condition code recorded between 1990 and 1995, between 1996 and 1999 and for the complete period.

\begin{tabular}{|c|c|c|c|c|c|c|}
\hline \multirow{2}{*}{$\begin{array}{l}\text { Condition } \\
\text { Code }\end{array}$} & \multicolumn{2}{|c|}{ 1990-1995 } & \multicolumn{2}{|c|}{ 1996-1999 } & \multicolumn{2}{|c|}{ 1990-1999 } \\
\hline & $\mathrm{N}$ & $\%$ & $\mathrm{~N}$ & $\%$ & $\mathrm{~N}$ & $\%$ \\
\hline 1 & 51 & 7.9 & 66 & 8.4 & 117 & 8.2 \\
\hline 2 & 60 & 9.3 & 128 & 16.2 & 188 & 13.1 \\
\hline 3 & 66 & 10.2 & 218 & 27.7 & 284 & 19.8 \\
\hline 4 & 232 & 36.0 & 271 & 34.4 & 503 & 35.1 \\
\hline Other & 236 & 36.6 & 105 & 13.3 & 341 & 23.8 \\
\hline Total & 645 & & 788 & & 1433 & \\
\hline
\end{tabular}

Codes: 1, live; 2, freshly dead; 3, moderate decomposition; 4, advanced decomposition. The category 'other' includes records with condition code 5 (skeletal remains) and those for which condition was unknown. $\mathrm{N}$, number; \%, percentage.
Kuiken's (1996) criteria for the diagnosis of by-catch. Where possible the type of fishing gear involved in bycatches was determined.

To assist in interpretation of seasonal patterns of strandings, information on the intensity and direction of geostrophic winds was derived from daily surface atmospheric pressure data (see Bakun, 1973; Lavín et al., 1991) to provide an 'upwelling index'. These data were obtained from the Spanish Meteorological Institute's recording station, located 150 miles west of Cape Finisterre.

\section{Analysis}

The data presented here include species composition, sex ratio, average size, and cause of death. Geographical, seasonal and interannual trends are described. To provide an index of the relative density of strandings along the six sub-areas of coastline, numbers of strandings were

Table 3. Strandings in each of the six coastal sub-areas. The table shows the percentage of coastline falling within in each sub-area and, for the main species and overall, the percentage of strandings occurring in that sub-area and a density index ( $D$, taking into account the relative length of coastline). Note: the sub-area is unknown for $5.4 \%$ of strandings of oceanic species*.

\begin{tabular}{|c|c|c|c|c|c|c|c|c|c|c|c|c|c|c|c|c|}
\hline \multirow{2}{*}{$\begin{array}{l}\text { Sub- } \\
\text { area }\end{array}$} & \multirow{2}{*}{$\begin{array}{c}\text { Coast- } \\
\text { line } \\
(\%)\end{array}$} & \multirow{2}{*}{$\begin{array}{c}\text { Total } \\
\text { strandings }\end{array}$} & \multicolumn{2}{|c|}{ Delphinus } & \multicolumn{2}{|c|}{ Phocoena } & \multicolumn{2}{|c|}{ Tursiops } & \multicolumn{2}{|c|}{ Stenella } & \multicolumn{2}{|c|}{ Grampus } & \multicolumn{2}{|c|}{$\begin{array}{l}\text { Oceanic } \\
\text { species* }\end{array}$} & \multicolumn{2}{|c|}{ All species } \\
\hline & & & $\%$ & $\mathrm{D}$ & $\%$ & $\mathrm{D}$ & $\%$ & $\mathrm{D}$ & $\%$ & $\mathrm{D}$ & $\%$ & $\mathrm{D}$ & $\%$ & $\mathrm{D}$ & $\%$ & $\mathrm{D}$ \\
\hline 1 & 11.6 & 69 & 1.0 & 5.0 & 1.9 & 1.4 & 1.9 & 2.2 & 6.1 & 3.6 & 0.0 & 0.0 & 10.7 & 4.3 & 4.8 & 49.8 \\
\hline 2 & 19.0 & 146 & 9.8 & 29.1 & 8.7 & 4.0 & 11.0 & 7.5 & 7.3 & 2.6 & 4.8 & 0.9 & 25.0 & 6.2 & 10.2 & 64.3 \\
\hline 3 & 25.0 & 286 & 16.3 & 36.8 & 7.8 & 2.7 & 26.0 & 8.7 & 31.7 & 8.7 & 14.3 & 2.0 & 26.8 & 5.0 & 20.0 & 95.7 \\
\hline 4 & 13.9 & 221 & 17.5 & 71.0 & 14.6 & 9.0 & 20.1 & 18.7 & 9.8 & 4.8 & 4.8 & 1.2 & 10.7 & 3.6 & 15.4 & 133.0 \\
\hline 5 & 17.6 & 461 & 35.2 & 112.7 & 40.8 & 20.0 & 33.8 & 24.7 & 30.5 & 11.9 & 59.5 & 11.9 & 19.6 & 5.2 & 32.2 & 219.2 \\
\hline 6 & 12.9 & 247 & 20.1 & 87.6 & 26.2 & 17.5 & 7.1 & 7.1 & 14.6 & 7.8 & 16.7 & 4.5 & 1.8 & 0.6 & 17.2 & 160.2 \\
\hline
\end{tabular}

*Oceanic spp. are: fin whale Balaenoptera physalus; minke whale Balaenoptera acutorostrata; humpback whale Megaptera novaeangliae; unidentified rorqual; Cuvier's beaked whale Ziphius cavirostris; sperm whale Physeter macrocephalus; pygmy sperm whale Kogia breviceps; killer whale Orcinus orca; Atlantic white-sided dolphin Lagenorhynchus acutus.

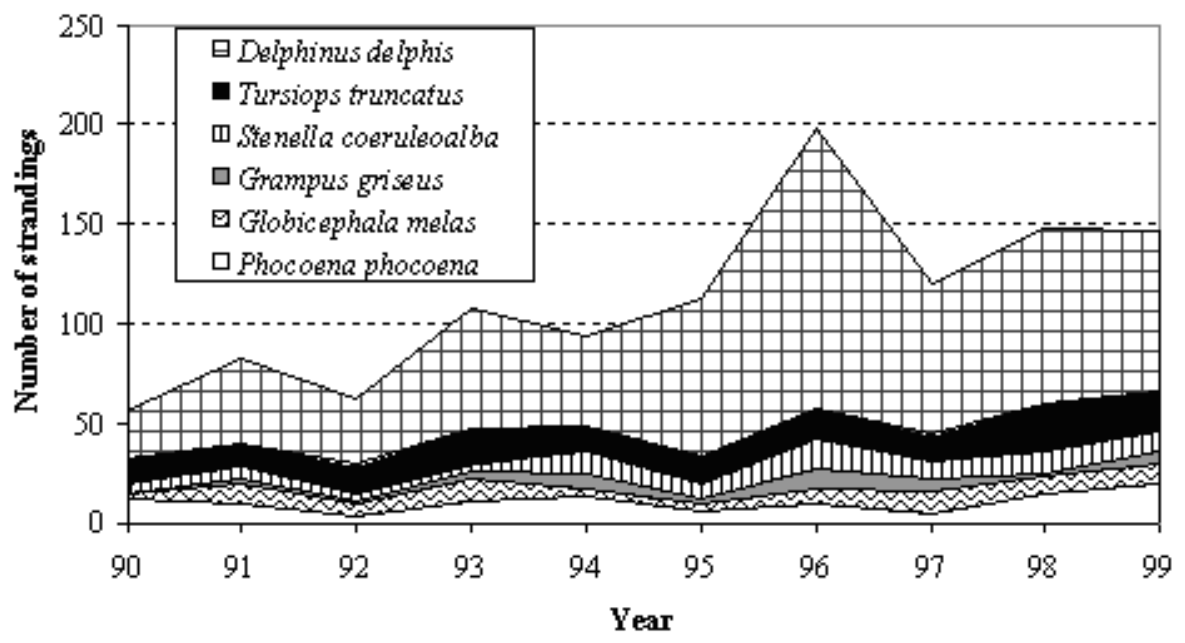

Figure 2. Year to year trends in reported strandings on the Galician coast 1990-1999 for the most commonly recorded species. 

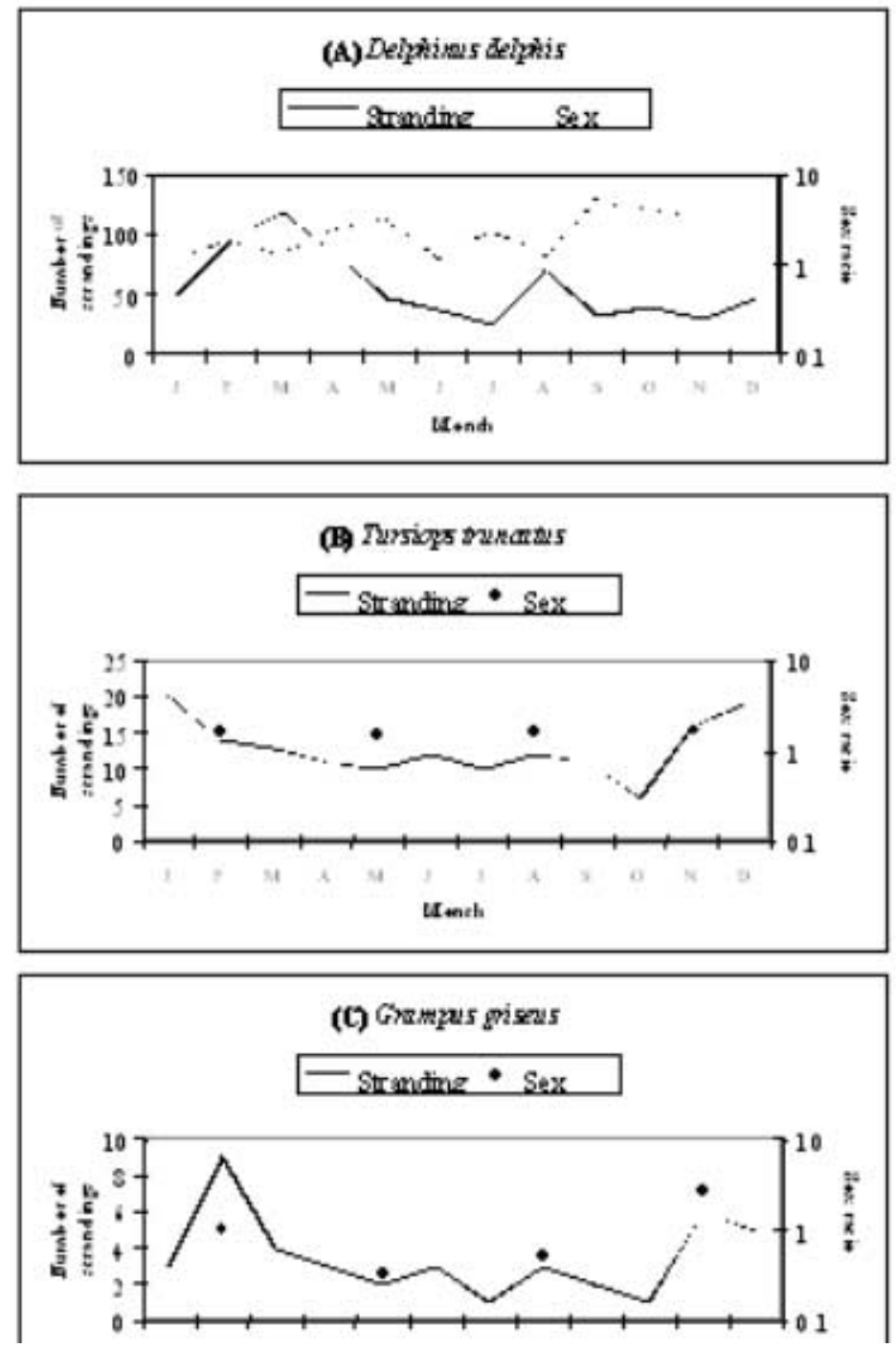

Figure 3A,B and C.

expressed in relation to coastline length, excluding islands, using coastline data derived from the GEBCO data-set (NERC, 1997). Although the GEBCO data underestimate the true coastline length, it is assumed that they are a reasonable index of the relative coastline length in each area. More detailed analysis was carried out on data on common dolphins (Delphinus delphis). This includes an analysis of data on body length and, for the last two years of the study (1998-1999), patterns in fishery by-catch. In all cases, the statistical significance of trends and differences was tested using standard non-parametric statistical tests (Zar, 1999).

\section{RESULTS}

\section{Species composition and geographical distribution}

A total of 1433 individuals belonging to at least 15 species of marine mammals was recorded in Galicia from 1990 to 1999 (Table 1). The majority of individuals were cetaceans, although seven pinnipeds were also recorded. Of the cetacean records, 20 were findings of skeletal remains and a further 206 records were of cetaceans for which species was not determined. The total also includes 42 directly reported by-catches of cetaceans by fishing boats. Live animals represented $8 \%$ of the records (six seals and 111 cetaceans; see Table 2). During 1996-1999, an average of 1.65 animals were stranded annually for each $10 \mathrm{~km}$ of coastline.

The common dolphin was the most frequently recorded species $(47 \%$ of the animals stranded). Other commonly recorded species were bottlenose dolphins Tursiops truncatus (11\%), harbour porpoises Phocoena phocoena (7\%), striped dolphins Stenella coeruleoalba $(6 \%)$, long-finned pilot whales Globicephala melas (5\%) and Risso's dolphins Grampus griseus (3\%).

Since 1996, coinciding with the organization of local groups of volunteers, the proportion of strandings of unknown condition (i.e. not visited or not located) has been markedly reduced (from $36 \%$ to $13 \%$, Table 2 ). The proportion of animals potentially yielding good biological samples (i.e. condition codes 2 and 3) increased from under $20 \%$ to over $40 \%$. Over the whole study period, total length could be measured for 796 animals $(55 \%)$. Estimated measurements were available for a further $21 \%$.

The incidence of recorded strandings was generally higher on the western coast of Galicia (sub-areas 3-6) than the northern coast (sub-areas 1-2), with the highest density of strandings being recorded in sub-area 5 (Table 3 ). 

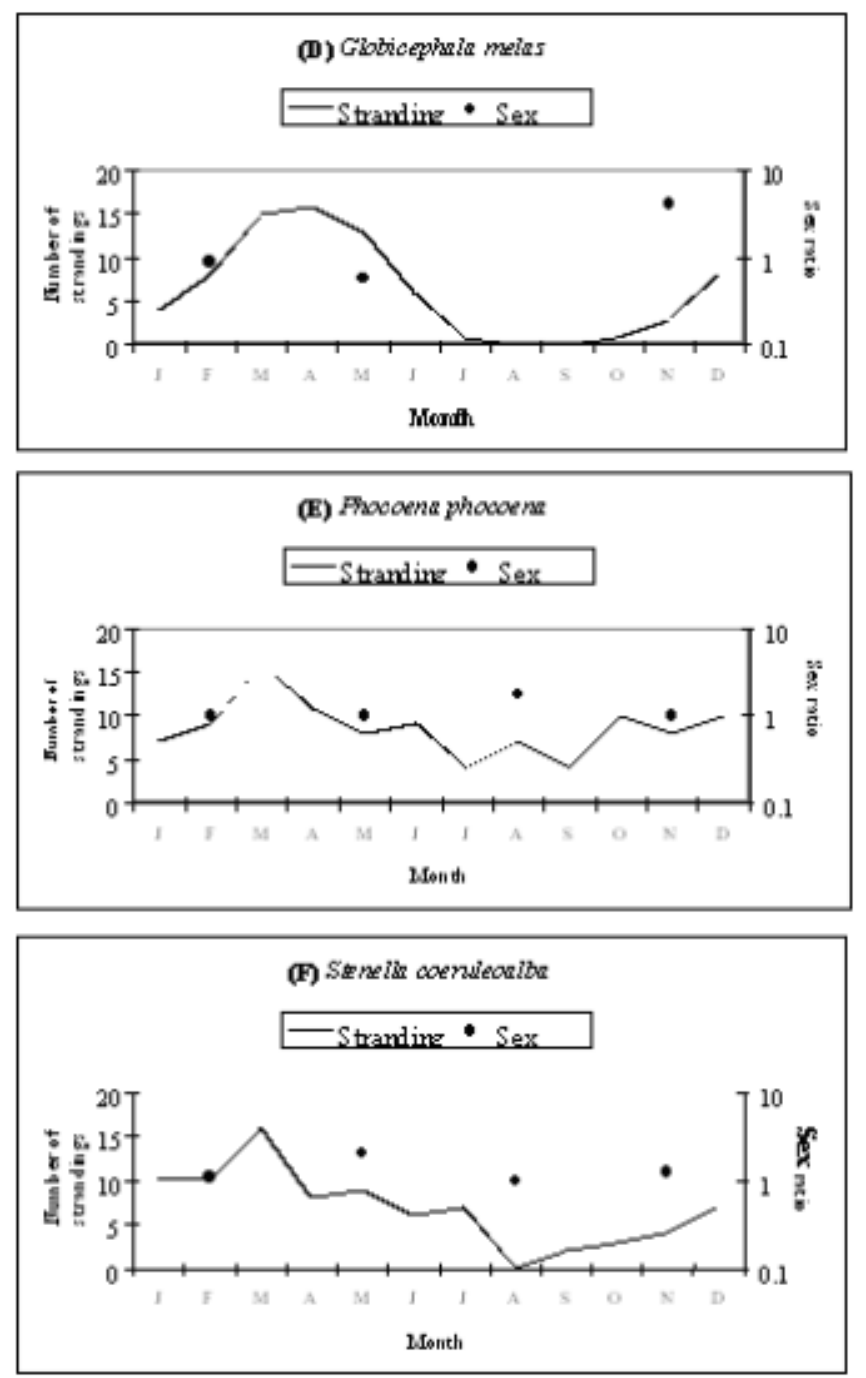

Figure 3. Seasonal trends in strandings and sex ratios, by species. All the graphs show monthly numbers of strandings. For common dolphins the monthly sex ratio is also displayed, for other species quarterly sex ratios are shown. Sample sizes are given in parentheses: (A) common dolphin Delphinus delphis; $(\mathrm{N}=673)$, (B) bottlenose dolphin Tursiops truncatus $(\mathrm{N}=154)$; $(\mathrm{C}) \mathrm{Risso's}$ dolphin Grampus griseus (N=42); (D) long-finned pilot whale Globicephala melas (N=75); (E) harbour porpoise Phocoena phocoena $(\mathrm{N}=103)$, ( $\mathrm{F})$ striped dolphin Stenella coeruloealba $(\mathrm{N}=82)$.

\section{Annual and seasonal trends in strandings}

During 1990-1999 there was a generally increasing trend in the annual total number of animals reported stranded (Figure 2). The correlation between calendar year and number of records is statistically significant (Spearman's $r=0.866, \mathrm{~N}=10, P<0.01$ ). The most striking increase was in common dolphin strandings $(\mathrm{R}=0.867$, $P<0.01)$ although there was also a significant upward trend in striped dolphin $(r=0.657, P<0.05)$ and bottlenose dolphin strandings $(r=0.661, P<0.05)$.

For common dolphins, there is a winter (March) peak in numbers of strandings (Figure 3). Winter peaks are also apparent in data from striped dolphins, harbour porpoises, long-finned pilot whales and Risso's dolphins; in the latter species there is a secondary peak in November. For bottlenose dolphins, the peak occurs in December and January. However, this peak is not as clear as those in the other species

Strandings of male common dolphins were generally more frequent than those of females (Figure 3): in all four quarters
Table 4. Total numbers and percentages of proven and diagnosed by-catches (see main text) recorded for the main cetaceans species.

\begin{tabular}{|c|c|c|c|c|c|c|}
\hline \multirow{2}{*}{$\begin{array}{l}\text { Cetacean } \\
\text { species }\end{array}$} & \multicolumn{2}{|c|}{$\begin{array}{c}\text { Proven } \\
\text { by-catch }\end{array}$} & \multicolumn{2}{|c|}{$\begin{array}{c}\text { Diagnosed } \\
\text { by-catch }\end{array}$} & \multicolumn{2}{|c|}{$\begin{array}{c}\text { Total } \\
\text { by-catch }\end{array}$} \\
\hline & $\mathrm{N}$ & $\%$ & $\mathrm{~N}$ & $\%$ & $\mathrm{~N}$ & $\%$ \\
\hline Delphinus & 22 & 3.3 & 133 & 19.8 & 155 & 23.0 \\
\hline Tursiops & 5 & 3.2 & 17 & 11.0 & 22 & 14.3 \\
\hline Phocoena & 4 & 3.9 & 19 & 18.4 & 23 & 22.3 \\
\hline Grampus & 1 & 2.4 & 11 & 26.2 & 12 & 28.6 \\
\hline Globicephala* & 4 & 5.3 & 8 & 10.7 & 12 & 16.0 \\
\hline Stenella & 0 & 0.0 & 4 & 4.9 & 4 & 4.9 \\
\hline Delphinid & 5 & 4.8 & 4 & 3.8 & 9 & 8.7 \\
\hline Balaenoptera & 1 & 10.0 & 2 & 20.0 & 3 & 30.0 \\
\hline Total & 42 & 3.4 & 198 & 15.9 & 240 & 19.3 \\
\hline
\end{tabular}

*This figure refers to Globicephala melas. N, number; \%, percentage of strandings of that species. 
Table 5. Annual distribution of proven by-catches ( $P B C$ ) and suspected by-catches ( $S B C$, see main text) recorded in Galicia between 1990 and 1999. The total by-catches are also expressed as a percentage of the total recorded strandings for each year.

\begin{tabular}{lllllllllllr}
\hline & 1990 & 1991 & 1992 & 1993 & 1994 & 1995 & 1996 & 1997 & 1998 & 1999 & TOTAL \\
\hline PBC & 3 & 2 & 2 & 4 & 1 & 1 & 8 & 4 & 4 & 13 & 42 \\
SBC & 1 & 5 & 8 & 15 & 12 & 25 & 50 & 29 & 30 & 23 & 198 \\
Total & 4 & 7 & 10 & 19 & 13 & 26 & 58 & 33 & 34 & 36 & 240 \\
$\%$ & 5.1 & 7.1 & 13.2 & 14.0 & 10.7 & 19.1 & 23.7 & 19.5 & 18.2 & 19.3 & 16.7 \\
\hline
\end{tabular}

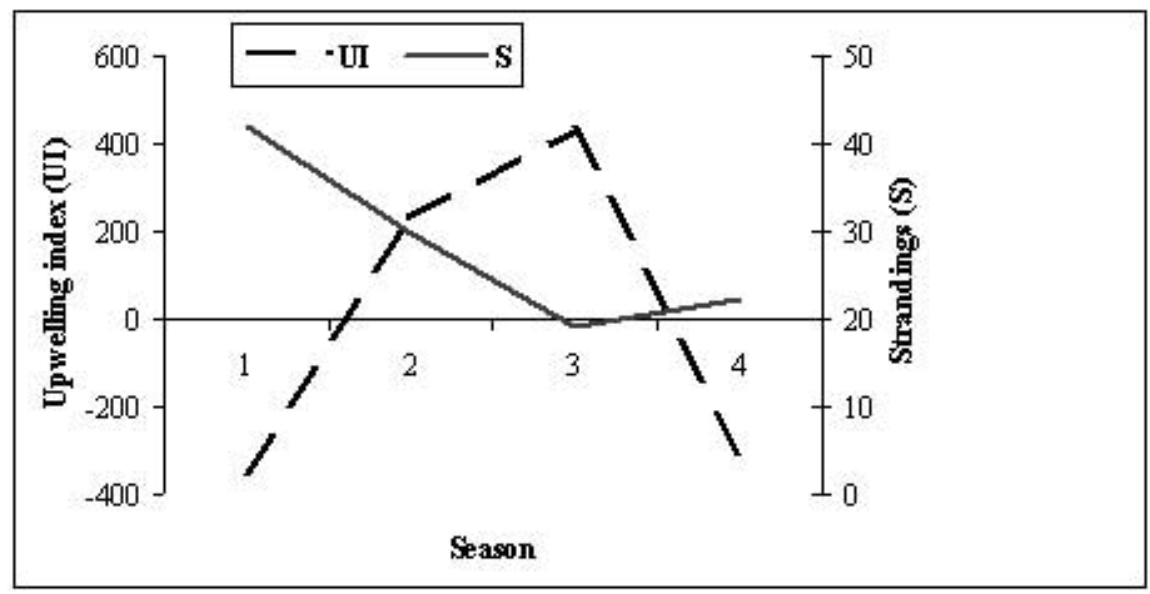

Figure 4. The seasonal pattern of the upwelling index, based on geostrophic winds, and annual average number of strandings of the main cetacean species, for the season, between 1990 and 1999.

males significantly outnumbered females $\left(\chi^{2}\right.$-tests, $\left.P<0.05\right)$. The bias towards males was higher towards the end of the year (homogeneity $\chi^{2}=10.54$, df=3, $P<0.05$ ). Sample sizes were smaller for the other species and quarterly (rather than monthly) sex ratios are therefore displayed (Figure 3). It should be noted that, in most species, up to a third of animals could not be sexed. For bottlenose dolphins, the overall sex ratio was biased towards males $\left(\chi^{2}=5.24\right.$, df $\left.=1, P<0.05\right)$ but sex ratios for each season did not differ significantly from $1: 1$. In the remaining species, sex ratios did not differ significantly from 1:1 ( $\chi^{2}$ tests). In the last quarter of the year, the pilot whales that stranded were predominantly males and very few of this species stranded in summer along the Galician coast (Figure 3D).
Fishery by-catches

A total of 42 cetaceans were reported by-catches. Among the strandings, 198 animals displayed signs of interaction with fishing gear (absence of tail/flippers, presence of ropes, net marks, ) and are regarded as probable by-catch mortality. Thus, the number of animals that had died due to interaction with fishing gear was probably at least 240 (Table 4). Around 23\% of common dolphin records and $29 \%$ of Risso's dolphins were proven or reported by-catches. The lowest proportion of by-catch mortality $(5 \%)$ was seen in striped dolphins. It should be noted that the number of reported by-catches each year is small but that there were higher numbers of diagnosed

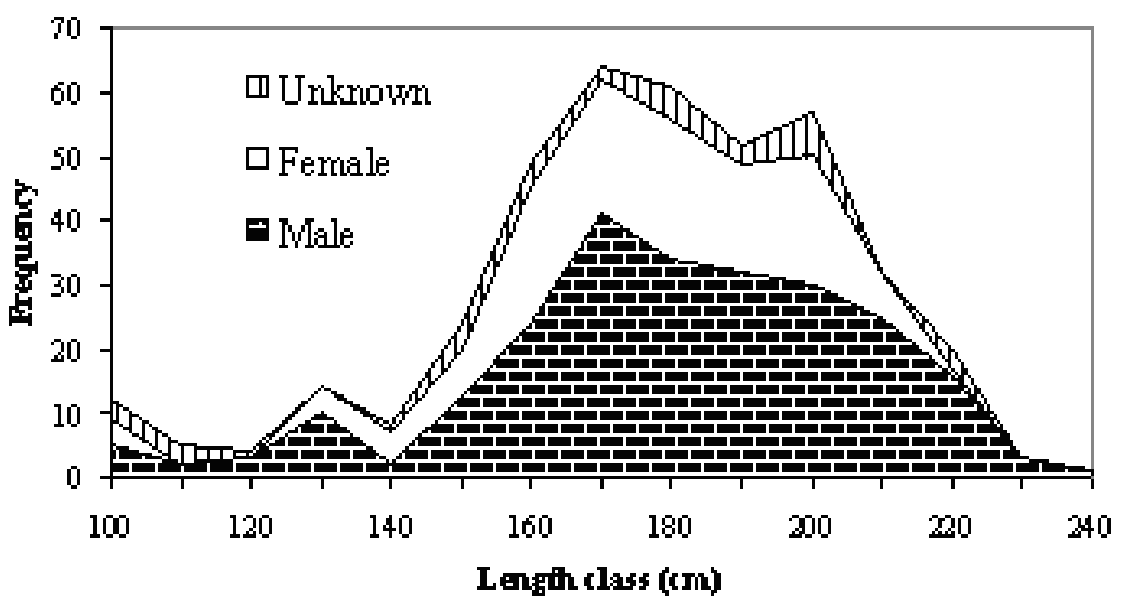

Figure 5. Frequency length distribution of common dolphin Delphinus delphis males, females and animals for which sex was not determined. Sample sizes are: males $(\mathrm{N}=241)$, females $(\mathrm{N}=129)$ and sex not determined $(\mathrm{N}=36)$. 
Table 6. Summary of coastline length, number of strandings, mean number of strandings (per year), mean number of strandings per $10 \mathrm{~km}$ of coast (per year) and number of species of marine mammals recorded, 1996-1998, for each area of the Atlantic Spanish and Portuguese coasts. Data from González (1999), Pérez et al. (1997), Sequeira et al. (1999) and the present study.

\begin{tabular}{|c|c|c|c|c|c|}
\hline Area & $\begin{array}{l}\text { Coastline } \\
(\mathrm{km})\end{array}$ & Strandings & $\begin{array}{c}\text { Annual } \\
\text { Mean }\end{array}$ & $\begin{array}{l}\text { Mean/ } \\
10 \mathrm{~km}\end{array}$ & $\begin{array}{c}\text { Number of } \\
\text { species }\end{array}$ \\
\hline Basque Country (northern Spain) & 256 & 25 & 8.3 & 0.3 & 6 \\
\hline Cantábria (northern Spain) & 283 & 40 & 13.3 & 0.5 & 5 \\
\hline Asturias (northern Spain) & 497 & 74 & 24.6 & 0.5 & 11 \\
\hline Galicia (north-west Spain) & 1195 & 601 & 200.3 & 1.7 & 13 \\
\hline Portuguese coast & 1023 & 350 & 116.6 & 1.1 & 12 \\
\hline Gulf of Cadiz (south-west Spain) & 294 & 39 & 13 & 0.4 & 9 \\
\hline Azores Islands (Portugal) & 700 & 58 & 19.3 & 0.3 & 10 \\
\hline Madeira Islands (Portugal) & 200 & 34 & 11.3 & 0.6 & 7 \\
\hline Canary Islands (Spain) & 1291 & 176 & 58.6 & 0.5 & 15 \\
\hline Total & 5739 & 1397 & & & 22 \\
\hline
\end{tabular}

by-catches during the last five years (Table 5). This may reflect the increasing effort and practical experience of the recorders.

\section{Trends in strandings and by-catches of common dolphins}

The winter (quarter 1) peak in common dolphin strandings is considerably more obvious than that seen for the other commonly recorded species and coincides broadly with the time of year when the upwelling index is lowest, with easterly winds predominating (Figure 4). However, the number of strandings was low in autumn, when eastward winds also prevail. There were fewest strandings in summer, when upwelling occurs due to the strong westward component of the winds.

Numbers of by-catches of common dolphins (data for 1998-1999 only) are highest in quarter 1 and, perhaps more importantly, form a higher proportion of records in quarter $1(34 \%)$ than in quarters $2-4(16,11$ and $9 \%$ respectively). Almost all these by-catches occurred in the southern part of the study area, particularly in sub-area 6 (Table 3).

Total length measurements were available for 406 common dolphins $(60.3 \%$ of the animals recorded), allowing construction of length-frequency distributions for males, females and animals for which sex was not determined $(\mathrm{N}=241,129$ and 36 respectively; see Figure 5). The total lengths of male dolphins ranged from 100 to $240 \mathrm{~cm}$, while lengths of females ranged from 100 to $220 \mathrm{~cm}$. Males were significantly longer on average than females (Kruskal-Wallis $H=5.32, P<0.05$, median male length $=184 \mathrm{~cm}$, female $=180 \mathrm{~cm})$.

There were significant seasonal differences in the average size of common dolphins stranded (KruskalWallis $H=10.23, \mathrm{df}=3, P=0.017)$. The smallest average size was in quarter 1 and the largest in quarter 3: median sizes for the four quarters were 179, 186, 190 and $186 \mathrm{~cm}$ respectively.

By-caught common dolphins in 1998-1999 ( $\mathrm{N}=39$ ) ranged in estimated size from 116 to $227 \mathrm{~cm}$ (median $166 \mathrm{~cm}$ ). It was not possible to detect any significant seasonal trend in the size of by-caught dolphins due to low sample sizes for quarters 2 to 4 . The majority of bycaught individuals were male (24, as compared to 13 females), the sex ratio thus being very similar to the overall sex ratio for all stranded animals (1990-1999).

\section{DISCUSSION}

It is clear from the number of strandings that the Galician coast supports substantial numbers of common dolphins. This is corroborated by recent sighting surveys (López et al., unpublished data). Of all areas along the Spanish and Portuguese Atlantic coasts, Galicia has the highest number and density of recorded cetacean strandings (see Table 6). While this may also reflect the efficiency of recording, the figures further emphasise the importance of the Galician coast as a habitat for marine mammals.

Recorded strandings on the Galician coast generally increased from 1990 to 1999. There is no doubt that the organization of recording of strandings improved during the 1990s, and public awareness of cetaceans has increased. However, inconsistencies in the trend (e.g. the peak in 1996 and subsequent drop in 1997) and differences in trends between species suggest that this is not a complete explanation. The seasonal winter/spring peak in strandings cannot be explained by differences in sampling effort. Strandings are more likely to be reported in the summer when recreational activity on the coastline is more intense.

Storms are more frequent during the autumn and winter and this could influence strandings, both by carrying carcasses towards the coast and by causing the death of animals in poor condition (Cendrero, 1993). In Galician waters the predominant winds from the south and southwest in winter would carry carcasses towards the coast. Similarly, the reverse direction of winds in spring and summer, associated with upwelling, may lead to a decrease in the number of carcases reaching the shore. However, the lower number of strandings in autumn is not consistent with this overall pattern, coinciding with prevalent easterly winds. Another factor to consider is seasonal migration. Different species of cetaceans undertake seasonal movements that lead to higher densities near the coast in certain seasons (Duguy, 1989). Common dolphins are not known to undertake welldefined migrations but seasonal shifts in distribution are reported off California (Leatherwood et al., 1983). These 
may be related to seasonal changes in prey distribution. The main prey in stomachs of common dolphins stranded in Galicia is blue whiting, scad and sardine (Santos, 1998). Blue whiting move closer inshore to spawn in spring (Whitehead et al., 1989) and dolphins may follow this spawning migration. Seasonal changes in the type, intensity or location of fishing activity may influence the number of by-catches. Landings of blue whiting from Spanish trawling fisheries in ICES fishery subdivisions 8C and 9A (Galicia and Gulf of Biscay coast) are generally higher in the first half of the year than in the second half of the year (Anonymous, 1996).

Another interesting feature of the seasonal pattern of strandings was the small average size of common dolphins stranded in the first quarter of the year. It is possible that this relates to the timing of breeding. The breeding season for this species in Galician waters, in July and August, is similar to that in Portuguese coastal waters, where most births occur in June and July (Silva, 1996), as compared to May and June on the Atlantic coast of France (Collet, 1981). The peak of strandings in the first quarter of the year is thus consistent with winter mortality of the youngest cohort in the population. In addition to natural mortality, inexperience of juveniles and/or different behaviour in the vicinity of fishing boats could lead to higher by-catch rates.

Perhaps the most striking feature of the strandings data is the predominance of male common dolphins among the stranded animals. Most males were smaller than $200 \mathrm{~cm}$ in length and most females were smaller than $190 \mathrm{~cm}$, the respective sizes at maturity according to Collet (1981) and Collet \& Saint Girons (1984). The under-representation of females and mature animals in the sample could be due to age- and sex-related habitat differences. Kuiken et al. (1994) found segregation, in relation to sexual maturity and sex, in common dolphin stranding locations on the south-west coast of England in 1992, suggesting the existence of at least two types of groups of dolphins, including separate groups of sub-adult males. Several other studies have documented biases towards juveniles in by-catches of common dolphins, e.g. in Portugal (M. Silva, 1996; R.P. Silva, 1996) and in the French albacore tuna drift gillnet fishery (Collet et al., 1992). However, these studies all recorded a sex ratio close to 1:1 in the by-catches.

More cetaceans were stranded on the West coast of Galicia than in the North, with the highest densities of strandings in sub-areas 4, 5 and 6. Several explanations are possible. Sub-areas 2, 4, 5, and 6 are highly influenced by winds from the south and south-west, which predominate during the winter, whereas the coastline in areas 1 and 3 is mainly orientated to the north. Areas 3,4 and 5 have long sandy beaches where stranded animals may remain for long periods of time, whereas areas 1 and 2 have mainly steep rocky coasts. Fishing activities take place all along the coastline but the effort is much higher offshore adjacent to areas 4, 5, and 6, which may result in more by-catches. The main prey species (blue whiting, scad, and sardine) are also important local fishery resources so dolphins and fishing may tend to concentrate in the same areas.

Quantifying the incidence of by-catches is one of the most controversial and problematical aspects of studies on stranded cetaceans. By-catch is recognized as a major threat to small cetaceans, especially the harbour porpoise (IWC 1994). Relatively few cetacean by-catches are directly reported by fishermen but by-catch mortality may also be diagnosed during necropsy of stranded animals, based on features such as score-marks in the skin caused by entrapment in the mesh of a net (Kuiken, 1996). In the present study, between $14 \%$ (bottlenose dolphin) and $29 \%$ (Risso's dolphin) of strandings of the most frequently recorded species were confirmed or diagnosed by-catches. This is likely to be an underestimate. Firstly, in the most recent years, increased experience of diagnosis of by-catch has led to an increased detection rate. Secondly, evidence of by-catch would not be detectable in badly decomposed animals. Most of the signs of by-catch observed were probably due to capture by gillnets (López \& Valeiras, 1997) and manipulation by fishermen to free animals from the net. However, entanglement may not always be fatal and animals that died from other causes may carry marks from previous entanglement.

Sampling work from March 1998 onwards and the present analysis were funded by CEC DG Fisheries Study Project 97/ 089. We thank all the members of CEMMA, the ECOBIOMAR research group at the Instituto de Investigaciones Marinas in Vigo, members of the public and various local authorities in Galicia for their assistance with data collection. We also thank to the Spanish Research Council (CSIC) and the Galician Government for funding recent research on marine mammals in Galician waters.

\section{REFERENCES}

Aguilar, A. \& Lens S., 1981. Preliminary report on Spanish whaling activities. Report of the International Whaling Commission, 31, 639-643.

Anonymous, 1996. Report of the Blue Whiting Assessment Working Group, Bergen, 23-29 April 1996. International Council for the Exploration of the Seas (CM Papers and Reports), C.M.1996/Assess, 14.

Bakun, A., 1973. Coastal upwelling indices, west coast of North America, 1946-1971. NOAA Technical Report NMFS SSRP, 671. US Department of Commerce. 103 p.

Cendrero, O., 1993. Nota sobre los hallázgos de cetáceos en el norte de España. Boletín del Instituto Español de Oceanografía, 9, 251-255.

Collet, A., 1981. Biologie du dauphin commun Delphinus delphis L. en Atlantique Nord-Est. PhD Thesis, Université de Poitiers, France.

Collet, A., Antoine, L. \& Danel, V., 1992. Preliminary report on the incidental catches of dolphins in the North-eastern Atlantic French tuna fishery. European Research on Cetaceans, 6, 19-24.

Collet, A. \& Saint-Girons, H, 1984. Preliminary study of the male reproductive cycle in common dolphins, Delphinus delphis, in the Eastern North Atlantic. Report of the International Whaling Commission, Special Issue, 6, 355-360.

Duguy, R., 1989. Migration, dispersion et erratisme chez les mammifères marins. Oceanis, 15, 207-211.

Fraga, F., 1981. Upwelling off the Galician coast, Northwest Spain. In Coastal upwelling (ed. F.A. Richards), pp. 176-182. Washington D.C.: American Geophysical Union.

González, A.F., 1999. Strandings and by-catches of marine mammals in the Spanish and Portuguese coasts from 1996 to 1998. International Council for the Exploration of the Seas (CM Papers and Reports), CM 1999/S:06.

IWC, 1994. Report of the workshop on mortality of cetaceans in passive fishing nets and traps. In Gillnets and Cetaceans (ed. W.F. Perrin et al.), pp. 1-71. Special Issue 15. Cambridge: International Whaling Commission. 
Kuiken, T., 1996. Review of the criteria for the diagnosis of by-catch in cetaceans. In Newsletter 26 (Special Issue): diagnosis of by-catch in cetaceans. Proceedings of the Second ECS Workshop on Cetacean Pathology (ed. T. Kuiken), pp. 38-43. Saskatoon, Saskatchewan, Canada: European Cetacean Society.

Kuiken, T. et al., 1994. Mass mortality of common dolphins (Delphinus delphis) in south west England due to incidental capture in fishing gear. Veterinary Record, 134, 81-89.

Lavín, A., Díaz del Río, G., Cabanas, J.M. \& Casas, G., 1991. Afloramiento en el noroeste de la Península Ibérica; índices de afloramiento para el punto $43^{\circ} \mathrm{N}, 11^{\circ} \mathrm{W}$. Informe Tecnico del Instituto Español de Oceanografía, 91, 33 pp.

Leatherwood, S., Reeves, R.R. \& Foster, L., 1983. The Sierra Club Handbook of Whales and Dolphins. Sierra Club Books, San Francisco.

López, A. \& Valeiras, X., 1997. Causes of mortality and suspected by-catches by gross post-mortem examination of cetacean strandings on the Galician coast (NW Spain). European Research on Cetaceans, 11, 42-44.

NERC, 1997. GEBCO Digital Atlas 1997. General Bathymetric Chart of the Oceans. IOC and IHO, British Oceanographic Data Centre, UK.

Penas-Patiño, X.M. \& Piñeiro-Seage, A., 1989. Cetáceos, focas e tartarugas das costas ibéricas. Consellería de Pesca, (Xunta de Galicia), Santiago de Compostela. 379 pp.

Pérez, C. et al., 1997. Stranding and by-catch of cetaceans in the Northeastern Atlantic during 1996. International Council for the Exploration of the Seas (CM Papers and Reports), C.M. 1997/Q:2.
Santos, M.B., 1998. Feeding ecology of harbour porpoises, common and bottlenose dolphins and sperm whales in the Northeast Atlantic. PhD thesis, University of Aberdeen, UK.

Sequeira, M. et al., 1999. Cetaceans strandings in the Northeastern Atlantic: the ATLANCETUS project. European Research on Cetaceans, 13, 260-181.

Silva, M., 1996. Contribuiçao para o conhecimiento de regime alimentare da biologia da reproduçao do golfinho-comum, Delphinus delphis Linnaeus, 1758, na costa Portuguesa. Master Thesis, Universidade de Lisboa, Portugal. 74 pp.

Silva, R.P., 1996. Age related mortality of common dolphin (Delphinus delphis) in Portuguese gillnet fisheries. European Research on Cetaceans, 10, 25-28.

Solórzano, M.R., Rodríguez, J.L., Iglesias, J., Pereiro, F.X. and Alvarez, F., 1988. Inventario dos peixes do litoral galego (Pisces: Cyclostomata, Condrichthyes, Osteichthyes). Cadernos da Area de Ciencias Biolóxicas. Seminarios de Estudios Galegos, vol. IV, 69 pp.

Whitehead, P.J.P., Bauchot, M.-L., Hureau, J.-C., Nielsen, J. \& Tortonese, E., ed., 1989. Fishes of the North-eastern Atlantic and the Mediterranean. UNESCO, Paris. $1461 \mathrm{pp}$.

Zar, J.M., 1999. Biostatistical. Analysis. Prentice Hall, New Jersey, 633 p. 